\title{
Aktualisasi Tanggungjawab Sosial Masyarakat pada Keluarga Miskin di Perdesaan: Studi Kasus Desa Pedalaman di Kabupaten Bone
}

\section{The Social Responsibility Actualitation to Poor Families at Rural Area}

\author{
Bustang $^{1 *}$, Basita G. Sugihen ${ }^{2}$, Margono Slamet ${ }^{2}$, dan Djoko Susanto ${ }^{3}$ \\ ${ }^{1}$ Badan Perencanaan Pembangunan Nasional, Jakarta \\ ${ }^{2}$ Departemen Sains Komunikasi dan Pengembangan Masyarakat, \\ Fakultas Ekologi Manusia, Institut Pertanian Bogor \\ ${ }^{3}$ Pusat Penelitian Gizi Departemen Kesehatan
}

\begin{abstract}
This research was intended to formulate the strategy to increase The Actuality and Social Responsibility to Poor Families at Rural Area. Survey were implemented among 57 selected samples, started Nopember 2006 until April 2007. Data was analyzed by using both correlation and path analysis. The results indicated that a number of respondent had a high social responsibility. The increasement of social responsibility and level of empowerment were influenced by implementation of good government of local organization, income, and formal education. This study suggests an alternative model of empowerment in order to social responsibility.
\end{abstract}

Key words: social responsibility, local instituiton, poor family

\section{PENDAHULUAN}

Tanggungjawab sosial seringkali diasosiasikan dalam pengertian kewajiban yang mestinya dilakukan oleh pihak tertentu. Padahal secara substansial itu tidak dapat dilepaskan dari kewajiban yang mestinya dilakukan oleh semua komponen masyarakat, swasta dan pemerintah. Hal tersebut, erat kaitannya dengan pelaksanaan dari tanggungjawab sosial dari berbagai aspek kehidupan, yang pada akhirnya akan berdampak positif kepada peningkatan kesejahteraan masyarakat secara keseluruhan.

Menurut ajaran agama tanggungjawab sosial banyak disebut sebagai kewajibankewajiban yang mestinya dilaksanakan oleh setiap ummat beragama "di antara harta-harta orang kaya terdapat sebagian harta orang-

\footnotetext{
* Korespondensi Penulis. Telepon: 08128080535
}

orang miskin". Dalam konteks ini, salah satu cara untuk mengukur tingkat konsistensi umat beragama bagi pemeluknya, ditunjukkan dengan sukarela, kedermawanan dalam membantu sesama yang kurang mampu untuk memberikan bantuan sesuai dengan aturanaturan agama yang dianutnya.

Konsepsi tanggungjawab sosial hakekatnya tidak terkait hanya persoalan agama saja, atau pada salah satu lembaga atau komponen saja, namun itu merupakan tanggungjawab kolektif. Oleh karena itu tanggungjawab sosial hakekatnya menjadi tanggungjawab semua pihak, yang merupakan kolektivitas melakukan tindakan dan upayaupaya menekan perilaku yang tidak etis, yang secara langsung atau tidak langsung dapat mengancam keamanan dan kenyamanan masyarakat dalam kehidupan sosial (Anonim, 2007). Dengan demikian hakekatnya tanggungjawab sosial harus melingkupi perlindungan terhadap masyarakat atau penduduk dan lingkungan fisik masyarakat dari berbagai 
Jurnal Penyuluhan, Maret 2009 Vol. 5 No. 1

ancaman yang dapat merugikan komunitas lokal.

Kotler dan Lee (2005) memandang bahwa tanggungjawab sosial merupakan suatu bentuk komitmen untuk meningkatkan kesejahteraan masyarakat melalui praktek atau kegiatan tertentu yang mempergunakan sumberdaya yang mereka miliki. Dalam hal ini terdapat kebebasan yang dimiliki individu atau kelompok masyarakat untuk mewujudkan kepeduliannya kepada kelompok masyarakat sasaran, baik dalam menentukan tujuan, jenis kegiatan, kelompok sasaran, alokasi sumberdaya yang dimiliki untuk kegiatan tersebut, dan sebagainya.

Seiring dengan krisis ekonomi yang mulai melanda Indonesia 1997, jumlah penduduk miskin kembali meningkat (Bappenas, 2003). Pada rentang 1997 - 2002, jumlah penduduk miskin tertinggi terjadi pada tahun 1998, yakni 49,5 juta jiwa atau 24,2 persen dari jumlah penduduk Indonesia. Namun demikian, dengan kecenderungan semakin membaiknya perekonomian Indonesia, maka tingkat kemiskinan terus menerus mengalami penurunan secara bertahap. Tahun 2004 jumlah penduduk miskin sekitar 36,1 juta jiwa atau 16,6 persen dari total jumlah penduduk (Bappenas, 2005). Kemiskinan tersebut tersebar di perkotaan dan perdesaan dengan rincian: (a) jumlah penduduk miskin di perkotaan 11,5 juta jiwa (12,6 persen); (b) jumlah penduduk miskin di perdesaan 24,6 juta jiwa (19,5 persen).

Permasalahan tentang kemiskinan yang menjadi sasaran kegiatan pemberdayaan membutuhkan komitmen masyarakat agar dapat berkontribusi pada: pembangunan memerlukan kerjasama dengan individu dalam kelompok tersebut, keluarga dan masyarakat dalam lingkup yang lebih besar untuk meningkatkan kualitas hidupnya. Contoh bentuk kegiatan tanggungjawab sosial menurut Kotler dan Lee (2005) yaitu: bidang kesehatan, keamanan, pendidikan, dan pelatihan kerja bidang tertentu. yang diberikan dapat berupa: dana (modal), pinjaman, biaya promosi, tenaga (bimbingan teknis tenaga ahli), peralatan/teknologi, akses informasi, dan sebagainya.
Berbagai latar belakang pemikiran tersebut, maka penting dipikirkan suatu upaya memampukan (empowering) kelompok miskin yang ada di dalam lingkungan masyarakat perdesaan melalui tanggungjawab sosial. Sebagaimana diyakini upaya berkelompok pada satuan individu miskin diduga lebih mengutamakan bagaimana hanya bisa bertahan untuk hidup tanpa memikirkan masa depannya. Oleh karena itu, perlu ada kearifan yang dapat melihat potensi serta faktor-faktor yang berpengaruh, mampu mendorong, memfasilitasi kesadaran (awareness) dan memunculkan kekuatan dirinya sendiri melalui tanggungjawab sosial bersama. Dengan demikian untuk mengubah kondisi masyarakat miskin di desa pedalaman dari ketidakberdayaan menjadi berdaya melalui aktualisasi tanggungjawab sosial, maka penelitian ini penting menjawab rumusan permasalahan adalah bagaimana tingkat aktualisasi tanggungjawab sosial masyarakat dalam membantu keluarga atau kelompok miskin di desa pedalaman? Faktorfaktor apa yang mempengaruhi tanggungjawab sosial masyarakat pada keluarga miskin? Bagaimanakah model pemberdayaan yang efektif untuk mening-katkan tanggungjawab sosial masyarakat? Adapun tujuan penelitian ini adalah menjelaskan tingkat aktualisasi tanggungjawab sosial masyarakat dalam membantu keluarga miskin di desa pedalaman Kabupaten Bone. Menjelaskan faktor-faktor yang mempengaruhi tanggungjawab sosial masyarakat pada keluarga miskin, dan merumuskan strategi peningkatan tanggungjawab sosial masyarakat.

\section{METODE PENELITIAN}

Populasi penelitian ini adalah seluruh anggota masyarakat di desa pedalaman Kabupaten Bone, yaitu individu yang telah berusia 17 tahun atau sudah menikah yang tinggal di wilayah perdesaan di Kabupaten Bone yang diwakili oleh Desa Maddenreng Pulu. Pengumpulan data dilakukan pada bulan Nopember 2006 sampai April 2007. Data primer diperoleh dengan mendatangi dan melakukan wawancara terhadap responden 
Jurnal Penyuluhan, Maret 2009 Vol. 5 No. 1

dengan berpedoman pada kuesioner yang diklarifikasi dengan wawancara mendalam dan wawancara bebas. Penentuan sampel dari populasi dilakukan dengan cluster sampling, jumlah sampel dihitung dengan rumus Slovin sehingga diperoleh jumlah 57 responden. Data dianalisis dengan: analisis tabel silang chi square, analisis korelasi product moment, dan analisis jalur.

\section{HASIL DAN PEMBAHASAN}

\section{Karakterisitik Responden}

Karakteristik masyarakat desa pedalaman di Kabupaten Bone yang direpresentasikan oleh sebagian warga masyarakat di Kecamatan Patimpeng Desa Maddareng Pulu yang diamati dalam penelitian ini meliputi jenis kelamin, umur, pendidikan formal, pendidikan non formal, jenis pekerjaan, dan tingkat pendapatan. Beberapa deskripsi responden ditampilkan pada Gambar 1.

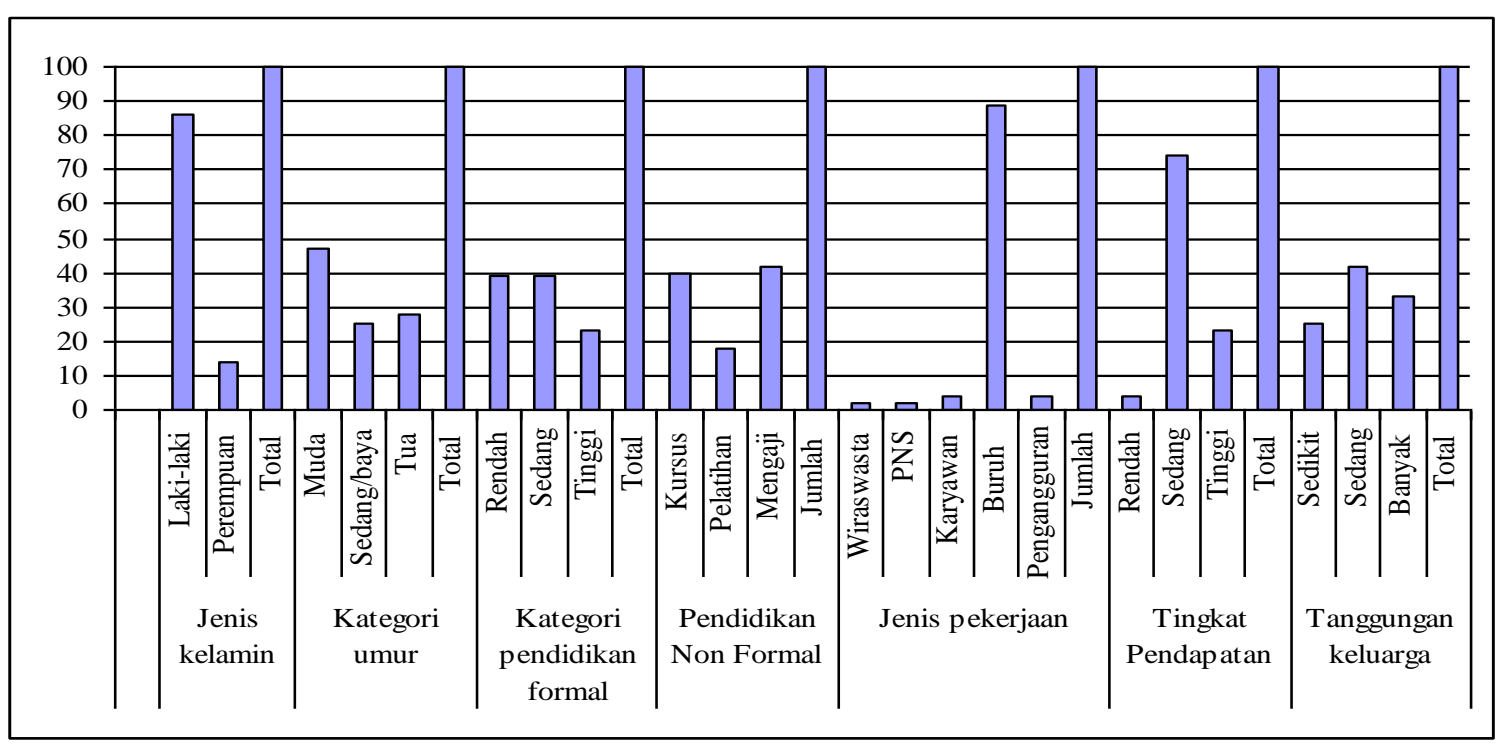

Gambar 1. Deskripsi Karakteristik Masyarakat

Berdasarkan Gambar 1, Sebagian besar responden berjenis kelamin laki-laki. Posisi laki-laki dalam masyarakat merupakan tulang punggung keluarga dalam mencari nafkah untuk memenuhi kebutuhan hidup keluarga. Kelompok umur masyarakat sebagian besar dikategorikan muda, yang menggambarkan bahwa kelompok ini adalah anggota masyarakat yang berpotensi sebagai tenaga kerja produktif di desanya. Kemudian mayoritas penduduk pedesaan adalah kelompok yang belum mampu menyelesaikan pendidikan tinggi. Pendidikan non formal yang diikuti pada umumnya adalah mengaji atau belajar ilmu agama (Islam). Tingkat pendapatan mayoritas responden adalah kelompok yang berpendapatan sedang. Umumnya kebutuhan pangan berasal dari hasil produksi menanam sendiri, jadi lebih banyak tidak dihitung sebagai pendapatan.

Peubah-peubah yang dikaji dalam penelitian ini terdiri dari: perilaku terhadap kemiskinan, peran kelembagan lokal yang meliputi pemerintah lokal/desa, organisasi sosial kemasyarakatan lokal/desa, perhatian dan tanggungjawab sosial, dan tingkat keberdayaan dideskripsikan pada Gambar 2. 
Jurnal Penyuluhan, Maret 2009 Vol. 5 No. 1

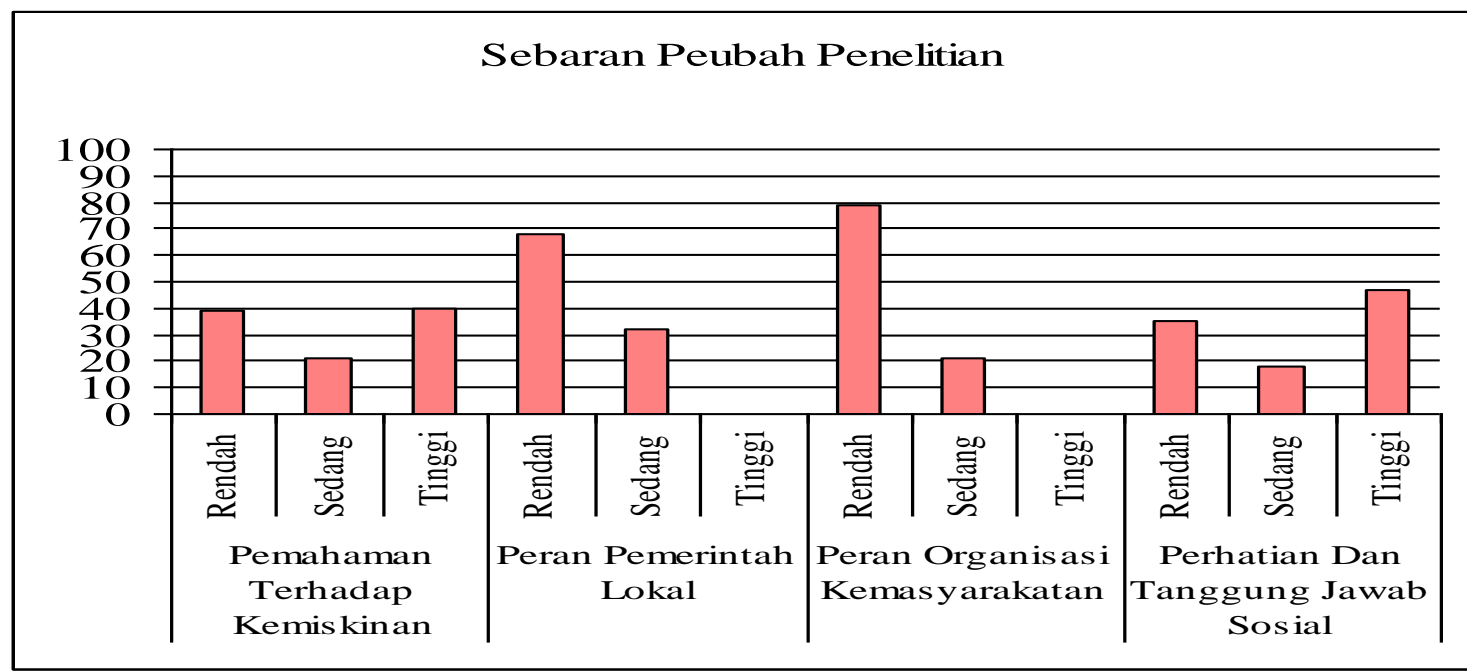

Gambar 2. Sebaran Responden Menurut Peubah Penelitian

Hasil analisis deskriptif menunjukkan bahwa pada umumnya pemahaman masya-rakat terhadap kemiskinan cukup baik, yang mengindikasikan bahwa kemiskinan dimaknai tidak saja pada kekurangan kebutuhan dasar manusia, tetapi terkait juga dengan kebutuhan sosial kemasyarakatan. Oleh karena itu, akan berimplikasi pada adanya kesadaran masyarakat bahwa penanganan masalah kemiskinan sebagai tanggungjawab semua pihak.

Peran kelembagaan lokal masih rendah khususnya pada organisasi masyarakat lokal/desa maupun dan pemerintah lokal/desa, yang ditunjukkan dari penilaian pada aspekaspek akuntabilitas, transparansi, partisipasi, daya tanggap dan komitmen, masih kategori rendah. Tingkat perhatian dan tanggungjawab sosialnya sebagain besar dalam kategori sedang dan mengarah pada kategori tinggi. Tingkat aktualisasi perhatian dan tanggungjawab masyarakat dalam menanggulangi kemiskinan cukup tinggi, yang diwujudkan dalam dua bentuk aktivitas utama yaitu kegiatan yang bersifat personal dan kegiatan yang bersifat kelompok atau kolektif.

\section{Aktualisasi Tanggungjawab Sosial Masyarakat Pada Keluarga Miskin}

Kondisi paktual dan aktual yang terlihat di tengah masyarakat adalah kemauan untuk menolong keluarga miskin, baik secara individu maupun kolektif. Aktivitas-aktivitas individu yang paling menonjol dalam konteks ini adalah pemberian bantuan langsung oleh individu kepada kelompok miskin. Umumnya aktivitas-aktivitas semacam ini dilakukan dalam dua bentuk kegiatan, yaitu: pemberian bantuan langsung kepada orang-orang sekitar yang membutuhkan baik dikenal maupun tidak dikenal. Bentuk kedua terutama terkait dengan pemberian bantuan langsung kepada sanak saudara yang berada pada status kurang mampu. Bentuk kedua ini umumnya sudah dilaksanakan secara turun temurun artinya sudah merupakan nilai-nilai yang diterima dalam keluarga. Selain itu terdapat perilaku membantu lain berupa implementasi nilainilai agama yaitu memberikan sedekah, zakat, dan bentuk-bentuk pemberian yang bersifat individu kepada kelompok miskin.

Bentuk-bentuk kegiatan kolektif umumnya dikoordinasikan oleh lembaga di tingkat desa, terutama terkait dalam jaringan kelembagaan keagamaan. Dalam hal ini bantuan umumnya diberikan kepada seorang tokoh masyarakat atau ulama untuk kemudian didistribusikan kepada keluarga miskin di perdesaan. Namun demikian, pengelolaan yang dilakukan melalui kelompok/organisasi kemasyarakatan masih dominan hanya sekedar konsumtif saja, bukan untuk usaha- 
Jurnal Penyuluhan, Maret 2009 Vol. 5 No. 1

usaha produktif dalam rangka memberdayakan keluarga miskin di perdesaan. Oleh karena usaha-usaha yang telah dirintis dan dikerjakan oleh individu maupun organissi kemasyarakatan lebih pada sekedar untuk memenuhi kebutuhan pangan saja, dan lebih bersifat jangka pendek, tidak untuk diinvestasikan sebagai modal tambahan.

Perhatian dan tanggungjawab sosial yang dimaksud dalam penelitian ini adalah aktualisasi perilaku membantu dalam bentuk fisik dan non fisik untuk mengurangi beban kelompok miskin baik yang dilakukan secara sengaja/terencana maupun yang tidak terencana, oleh individu maupun kelompok, terorganisasi maupun tidak terorganisasi. Dengan kata lain perhatian tanggungjawab sosial merupakan aktivitas/tindakan individu atau kelompok untuk membantu kelompok miskin di pedesaan yang dikelompokkan dalam tiga katagori yaitu tinggi, sedang, dan rendah. Selanjutnya untuk mengetahui gambaran mengenai perhatian dan tanggungjawab sosial responden terhadap kelompok miskin di perdesaan disajikan pada Gambar 3.

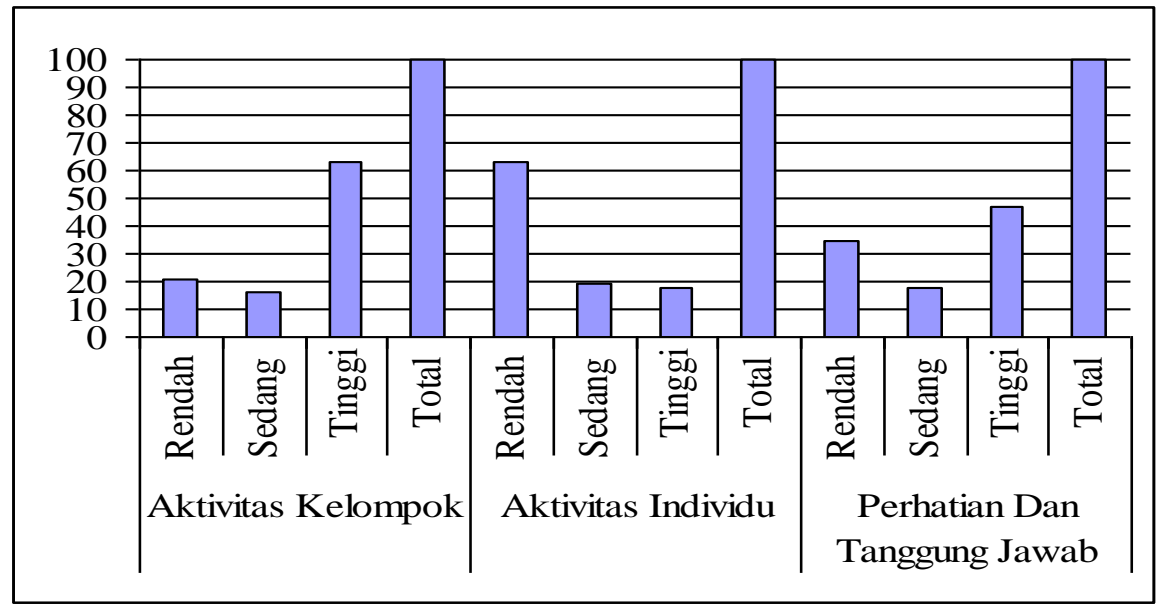

Gambar 3. Diskripsi Perhatian dan Tanggung Jawab Sosial Responden terhadap Kelompok

Gambar 3 menunjukkan bahwa perhatian dan tanggungjawab sosial responden terhadap permasalahan kemiskinan sebagian besar dikategorikan sedang. Berbagai aktivitas yang dikategorikan sebagai aktivitas individu dalam memberdayakan keluarga miskin umumnnya dikelompokkan sedang, artinya aktivitas individu sudah dilaksanakan cukup baik. Kondisi agak berbeda ditunjukkan pada aktivitas yang dilaksanakan secara kelompok atau kolektif. Pada aktivitas yang dikelompokkan sebagai tindakan kelompok masih dikategorikan rendah, artinya aktivitasaktivitas berupa upaya membantu dalam proses pemberdayaan keluarga miskin belum optimal dilaksanakan secara berkelompok. Kedua fakta ini memberikan gambaran bahwa walaupun telah terjadi kesadaran dan aktualisasi dalam membantu proses pemberdayaan kelompok miskin terutama di tingkat individu, namun kegiatan-kegiatan tersebut masih belum optimal karena belum terkoordinasikan secara kolektif dengan baik.

Secara Paktual masyarakat Desa Maddanreng Pulu memiliki tingkat perhatian dan tanggungjawab sosial cukup tinggi. Hal ini menunjukkan bahwa proses pelaksanaan bantuan secara individu atau personal dari masyarakat Maddanreng Pulu kepada kelompok kurang mampu relatif baik. Hal tersebut disebabkan oleh kepala desa yang kebetulan adalah warga asli turun temurun dari desa yang bersangkutan, senantiasa aktif 
Jurnal Penyuluhan, Maret 2009 Vol. 5 No. 1

untuk mengajak masyarakat dalam upaya melaksanakan aktivitas kemasyarakatan.

Aktualisasi perhatian dan tanggungjawab sosial secara individu atau personal sudah dilakukan dan melembaga, namun pada sisi lain dalam banyak hal perbantuan kepada kelompok miskin secara kolektif dan terkoordinasikan masih belum banyak dijalankan secara baik. Pada dasarnya proses mengorganisasikan kegiatan-kegiatan yang masih bersifat individual adalah penting mengingat beberapa dampak positif yang dapat diperoleh. Pengorganisasian kegiatan atau aksi-aksi individu dapat mendatangkan sinergi potensi yang dapat memberikan energi yang lebih besar dalam proses pemberdayaan keluarga miskin. Disamping itu aksi-aksi kolektif secara psikologis dapat memberikan manfaat terutama pada keluarga miskin bahwa mereka tidak merasa sendiri (teralienasi) dari lingkungan.

Kegiatan produktif yang dilakukan masyarakat antara lain pembuatan batu merah, kegiatan berkebun kacang-kacangan dan sayuran lainnya yang dijual tidak hanya di desa/kecamatan tersebut tapi sampai pada lintas kabupaten. Kegiatan ekonomi yang menghasilkan nilai tambah dijual kepada pengumpul yang biasanya datang ke lokasi untuk membeli hasil pertanian mereka seperti gabah, sayuran, dan kacang-kacangan. Aktivitas-aktivitas lain yang dilakukan oleh masyarakat secara individu dalam menanggulangi kemiskinan banyak dilakukan dengan cara memberikan pekerjaan kepada keluarga miskin yaitu ikut membantu pemilik lahan dalam menggarap sawah, kebun dengan sistem penggajian atau upah harian, atau bagi hasil. Kegiatan ekonomi lainnya adalah ikut menjadi tenaga buruh pada industri pembuatan batu merah, buruh pabrik, khususnya pada saat pabrik gula melakukan musim tanam tebu. Hal tersebut dilakukan karena Desa Maddareng Pulu berbatasan langsung dengan Kecamatan Camming yang merupakan lokasi salah satu BUMN PT. Pabrik Gula Bone.

Sebaliknya aktivitas membantu
keluarga miskin yang dilakukan oleh
masyarakat secara individu berhubungan

nyata dan negatif dengan kemampuan keluarga miskin dalam berinteraksi sosial. Semakin tinggi aktivitas-aktivitas yang dilakukan secara individu dalam membantu kelompok miskin semakin rendah kemampuan kelompok miskin dalam berinteraksi sosial. Kondisi ini terkait dengan nilai-nilai yang ada pada masyarakat lokal, dimana proses atau upayaupaya yang dilakukan oleh individu dalam membantu orang miskin kerap kali disertai dengan upaya-upaya pemberian nasehat atau saran untuk melaksanakan kegiatan produktif yang bermanfaat. Namun yang banyak ditemui dalam penelitian ini, sebagian besar penerima bantuan mempersepsi kurang positif terhadap nasehat tersebut sehingga berdampak pada meningkatnya keengganan untuk berinteraksi sosial baik kepada individu pemberi bantuan atau anggota masyarakat lain yang mengetahuinya. Kondisi yang demikian ini, juga banyak dipicu oleh perasaan minder atau kurang percaya diri, sehingga merasa terasingkan (teralienasi) dalam sistem sosial.

Terdapat kecenderungan bantuan secara individual yang semakin meningkat terhadap keluarga miskin, akan berdampak pada semakin menurunkan tingkat intensitas keluarga miskin dalam melakukan kegiatankegiatan yang produktif. Hal yang demikian terjadi karena bantuan individual, senantiasa hanya dimanfaatkan oleh sebagian kecil keluarga miskin sebagai suatu keuntungan sejenak saja. Demikian pula, segenap bantuan untuk keluarga miskin, dari pemerintah yang sifatnya langsung dalam bentuk dana segar akan berdampak kurang bagus dalam rangka pemberdayaan keluarga miskin. Hal tersebut tercermin dari perilaku dari sebagian keluarga miskin yang hanya mengharapkan bantuan, baik bantuan individu maupun bantuan dari pemerintah pusat maupun pemerintah daerah.

Pada sisi lain, upaya-upaya atau aksiaksi anggota masyarakat yang dilakukan secara kolektif sebagai upaya untuk memfasilitasi tumbuhnya aktivitas produktif di masyarakat juga telah dilakukan. Namun demikian, terdapat beberapa keluarga miskin yang merasa enggan untuk terlibat langsung, yang lebih disebabkan oleh kondisi psikologis, karena keluarga miskin yang demikian merasa 
Jurnal Penyuluhan, Maret 2009 Vol. 5 No. 1

terasing dari komunitas yang ada di lingkungannya. Perasaan yang demikian harus dihilangkan melalui interaksi positif melalui aksi-aksi masyarakat kepada keluarga miskin di perdesaan.

Secara umum fakta-fakta di atas memberikan petunjuk bahwa upaya-upaya memberdayakan keluarga miskin sudah dilakukan oleh anggota masyarakat, khususnya melalui aksi-aksi individu. Namun demikian proses atau upaya penanggulangan kemiskinan tersebut belum secara sistematis, terkoordinasikan, dan terlembagakan dalam melaksanakannya. Konsekuensinya, upaya pengentasan kemiskinan yang telah dilakukan perlu dikoordinasikan kembali, terutama dalam menemukan cara yang paling efektif secara kolektif dan terlembagakan dalam masyarakat. Upaya ini dilakukan agar aktivitas pemberdayaan keluarga miskin dapat berjalan secara berkesinambungan, melalui usaha produktif.

Secara Paktual dapat dijelaskan bahwa potensi-potensi peran masyarakat dan kelembagaan lokal dalam memberdayakan keluarga miskin cukup tinggi. Potensi tersebut terbangun melalui nilai-nilai yang ada dalam masyarakat yaitu pemahaman, sikap, dan kepercayaan bahwa kemiskinan pada dasarnya dapat diatasi secara bersama, dan yang paling penting adalah aktivitas-aktivitas individu maupun kelompok yang secara nyata telah melakukan upaya-upaya dalam memberdayakan keluarga miskin.

Sudah terdapat tingkat pemahaman terhadap kemiskinan yang tepat dan positif, bahwa kemiskinan dapat ditanggulangi, melalui upaya yang dilakukan oleh pemerintah maupun oleh organisasi kemasyarakatan. Kemudian dengan pemahaman yang tepat tersebut, maka dapat meningkatkan perhatian dan tanggungjawab sosial masyarakat dalam bentuk tindakan nyata dalam rangka menanggulangi kemiskinan. Tindakan-tindakan nyata tersebut dapat berbentuk tindakan kolektif atau upaya-upaya kolektif yang dilaksanakan dalam rangka usaha untuk mengatasi masalah keluarga miskin.
Hasil analisis menunjukkan hubungan pemahaman terhadap kemiskinan dengan perhatian dan tanggungjawab sosial dalam mengatasi kemiskinan adalah 0,255 dan signifikan pada $\alpha=0,01$. Kondisi ini menunjukkan bahwa terdapat hubungan nyata dan positif antara kedua variabel tersebut. Artinya semakin tinggi dan positif tingkat pemahaman individu terhadap kemiskinan, maka semakin besar pula upaya-upaya yang dilaksanakan dalam kaitan dengan permasalahan kemiskinan sebagai bentuk perhatian dan tanggungjawab sosial. Oleh karena itu, tingkat pemahaman yang tinggi pada kemiskinan dan adanya kepercayaan yang positif bahwa kemiskinan dapat diatasi, mendorong dan menjadi motif bertindak masyarakat desa pedalaman dalam meng-aktualisasikan prilakunya untuk membantu secara individu maupun kelompok dalam menanggulangi permasalahan kemiskinan. Hal ini juga berarti bahwa upaya-upaya penanggulangan kemiskinan dipandang sebagai salah satu aktivitas yang penting dalam kehidupan masyarakat Bone.

Hal serupa ditunjukkan pada hubungan antara peran kelembagaan lokal dengan perhatian dan tanggungjawab sosial dalam mengatasi kemiskinan. Persepsi yang sangat positif terhadap peran kelembagaan lokal dalam mengimplementasikan tata kepemerintahan yang baik, membantu masyarakat untuk semakin optimis dalam melakukan upaya-upaya penanggulangan kemiskinan. Dalam konteks ini, kepercayaan yang tumbuh dari individu yang ditopang oleh lingkungan yang mendukung semakin meningkatkan kepercayaan individu untuk melangkah membantu keluarga miskin secara kolektif.

\section{Strategi Peningkatan Tanggungjawab Sosial Masyarakat pada Keluarga Miskin}

Pilihan strategi peningkatan tanggungjawab sosial masyarakat pada keluarga miskin di desa pedalaman ditunjukkan pada Gambar 4.

Strategi pertama sebagai prioritas pertama adalah perhatian dan tanggungjawab 
Jurnal Penyuluhan, Maret 2009 Vol. 5 No. 1

sosial akan memberikan harapan hidup yang lebih terjamin bagi keluarga miskin karena upaya nyata secara individu maupun kolektif masyarakat setempat. Perhatian dan tanggungjawab sosial dapat dicapai melalui peningkatan pemahaman masyarakat desa terhadap kemiskinan. Pemahaman dapat dicapai melalui peran-peran yang nyata dari kelembagaan organisasi masyarakat. Peran

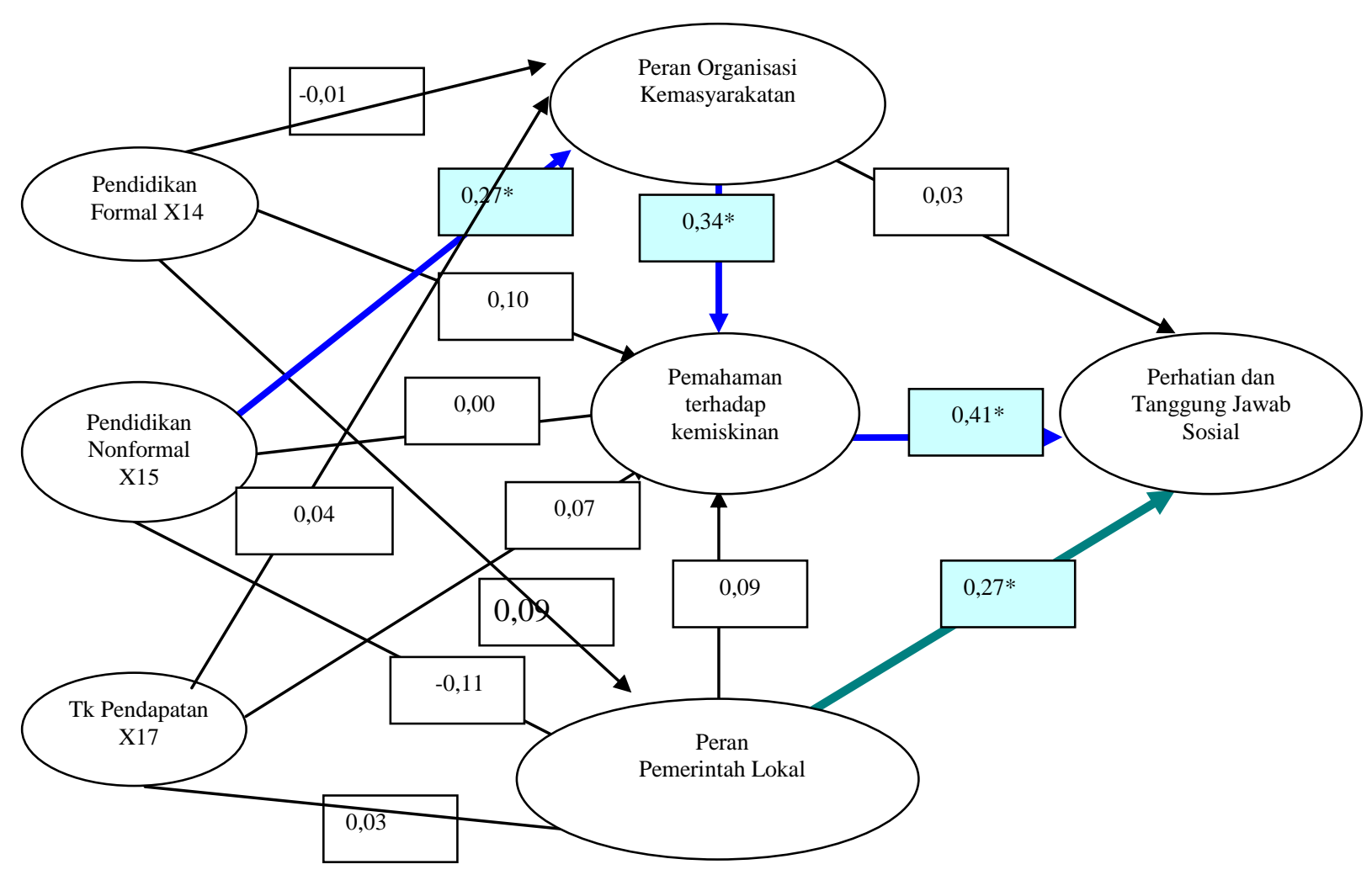

Keterangan: $\longrightarrow:$ Jalur alternatif/prioritas pertama

Gambar 4: Model Empirikal Strategi Peningkatan Tanggung Jawab Sosial Masyarakat pada Keluarga Miskin di Desa Pedalaman

kelembagaan lokal dalam hal ini adalah memberikan fasilitasi bagi aktivitas kolektif membantu keluarga miskin sekaligus sebagai tempat dimana internalisasi nilai-nilai dan pemahaman terhadap kemiskinan terjadi. Interaksi antar anggota dalam suasana dan iklim yang positif akan menguatkan dan menjadi proses pembelajaran yang sangat efektif. Peran kelembagaan dalam hal ini organisasi masyarakat dapat dicapai melalui peningkatan kualitas dari pendidikan nonformal. Penguatan proses pendidikan dan sarana pendidikan akan mempengaruhi kualitas hasil belajar yang diterima. Dengan demikian upaya-upaya peningkatan pada pendidikan nonformal menjadi sangat strategis dilaksanakan pada masyarakat Desa Maddenreng Pulu.

Alternatif kedua yang dapat dilaksanakan adalah peningkatan peran 
Jurnal Penyuluhan, Maret 2009 Vol. 5 No. 1

kelembagaan lokal (pemerintahan lokal/desa) dalam hal ini pemerintahan desa. Peningkatan kualitas dan komitmen SDM kelembagaan lokal (pemerintahan lokal/desa) yang jelas akan memudahkan pencapaian dan peningkatan perhatian dan tanggungjawab sosial masyarakat kepada kelompok miskin. Peran yang jelas, citra yang positif, SDM yang memiliki orientasi pelayanan yang prima akan memberikan dampak kepercayaan pada masyarakat akan keseriusan masyarakat dalam memfasilitasi pemberdayaan keluarga miskin. Upaya mencapai peningkatan kualitas peran kelembagaan organisasi pemerintah lokal dapat dicapai melaui proses pendidikan formal. Artinya keberdayaan masyarakat desa khususnya keluarga miskin harus didahului peningkatan proses pendidikan yang berkualitas. Nampak jelas di Desa Maddenreng Pulu faktor pendidikan (pendidikan nonformal dan pendidikan formal) menjadi fundamental dalam meningkatkan keberdayaan keluarga miskin. Aspek pendidikan menjadi dasar penguatan dan peningkatan perhatian dan tanggungjawab sosial masyarakat pada keluarga miskin.

\section{KESIMPULAN}

Terdapat pemahaman yang cukup tinggi bahwa kemiskinan tidak saja berdimensi fisik akan tetapi memiliki dimensi lain yaitu dimensi-dimensi non fisik, masyarakat memiliki sikap yang setuju bahwa kemiskinan adalah bagian dari masalah bersama sehingga perlu ditang-gulangi secara bersama-sama. Terdapat kesepakatan bahwa kemiskinan tidak hanya menjadi tanggungjawab pemerintah, akan tetapi semua komponen masyarakat memiliki kewajiban dan peran yang sama pentingnya. Dengan demikian apabila kondisi kewajiban bersama ini dapat dilaksanakan maka terdapat keyakinan yang besar bahwa kemiskinan akan dapat ditanggulangi melalui upaya-upaya pemberdayaan masyarakat miskin secara sistematis dan berkesinambungan.

Terdapat hubungan yang nyata antara pemahaman terhadap kemiskinan dengan perhatian dan tanggungjawab sosial dalam mengatasi kemiskinan. Artinya semakin tinggi dan positif tingkat pemahaman individu terhadap kemiskinan, maka semakin besar pula upaya-upaya yang dilaksanakan yang berkaitan dengan permasalahan kemiskinan sebagai bentuk perhatian dan tanggungjawab sosial.

Terdapat aksi nyata yang umumnya dilaksanakan secara individu dalam membantu orang miskin. Bantuan-bantuan yang dilakukan secara individu telah dilaksanakan secara sukarela dalam bentuk sedekah atau bantuan langsung. Umumnya pelaksanaan bantuan tersebut tanpa koordinasi dan umumnya diberikan pada keluarga terdekat disamping kepada orang lain. Upaya-upaya bantuan secara kelompok melalui koordinasi oleh lembaga tertentu belum optimal dijalankan. Kondisi ini disebabkan antara lain oleh pemahaman bahwa yang dimaksud bantuan kepada kelompok miskin lebih efektif dilakukan sendiri, karena dapat diterima langsung kelompok miskin yang bersangkutan.

\section{DAFTAR PUSTAKA}

Bappenas. 2003. Peta Kemiskinan di Indonesia. Bappenas: Jakarta.

2005. Penerapan Tata Kepemerintahan Yang Baik. Sek PKN Tata Kepemerintahan Yang Baik. Bappenas: Jakarta.

Kotler, P. dan Lee, N. 2005. Corporate Social Responsibility. New Jersey: John Wiley \& Sons, Inc. 